\title{
PERBEDAAN TINGKAT KEBUGARAN JASMANI SISWA KELAS UNGGUL DAN KELAS REGULER DI SEKOLAH MENENGAH PERTAMA NEGERI 4 KOTA PARIAMAN
}

\author{
Sepriadi, Zalfendi, Mardayanti ${ }^{4)}$
}

\begin{abstract}
ABSTRAK
Masalah dalam penelitian ini karena belum diketahuinya tingkat kebugaran jasmani antara siswa kelas unggul dengan sisw kelas reguler. Tujuan penelitian ini adalah untuk melihat perbedaan tingat kebugaran jasmani siswa kelas unggul dengan kelas reguler di SMP Negeri 4 Pariaman.Jenis penelitian ini adalah penelitian komparatif. Populasi dalam penelitian ini adalah seluruh siswa SMP Negeri 4 Pariaman sebanyak 611 siswa. Teknik penarikan sampel dalam penelitian ini menggunakan teknik purposive sampling. Sampel dalam penelitian ini adalah 29 siswa dari kelas unggul dan 26 siswa dari kelas regular. Instrumen dalam peneelitian ini menggunakan Tes Kesegara Jasmani Indonesia (TKJI) untuk usia 13-15 tahun. Analisis data menggunakan uji t independent sampel dengan jumlah sampel berbeda. Hasil dalam penelitian ini menunjukkan bahwa tidak terdapat perbedaan tingkat kesegaran jasmani siswa kelas unggul dengan kelas reguler. Diman $t_{\text {hit }}(1,625)<t_{\text {tab }}$ $(1,676)$. Hal ini berarti bahwa tidak terdapat perbedaan tingkat kebugaran jasmani antara siswa kelas unggul dengan kelas reguler.
\end{abstract}

Kata Kunci: Kelas Unggul, Kebugaran Jasmani, Kelas Reguler

\section{PENDAHULUAN}

Pendidikan merupakan salah satu bidang yang memegang peranan penting untuk pembangunan bangsa dan negara Indonesia. Tujuan pendidikan adalah untuk mengembangkan sumber daya manusia sedini mungkin secara terarah, menyeluruh dan optimal serta sehat jasmani dan rohani berlandaskan Pancasila. Tujuan pendidikan pada dasarnya adalah untuk meningkatkan kualitas sumber daya manusia. Salah satu upaya untuk meningkatkan kualitas sumber daya manusia tersebut adalah melalui pendidikan jasmani. Pendidikan jasmani merupakan bagian yang tidak terpisahkan dari program pendidikan keseluruhan yang disempurnakan, juga merupakan suatu proses melalui aktifitas jasmani yang dirancang dan disusun secara

4) Sepriadi. Saat ini Dosen Jurusan Pendidikan Olahraga Fakultas Ilmu Keolahragaan Universitas Negeri Padang

4) Zalfendi. Saat ini Dosen Jurusan Pendidikan Olahraga Fakultas Ilmu Keolahragaan Universitas Negeri Padang

4) Mardayanti. Saat ini Mahasiswa Jurusan Pendidikan Olahraga Fakultas Ilmu Keolahragaan Universitas Negeri Padang 
sistematik, untuk merangsang pertumbuhan dan perkembangan, meningkatkan kemampuan dan keterampilan jasmani. Hal ini sesuai dengan Paturisi (2012:5) menjelaskan bahwa pendidikan jasmani adalah suatu kegiatan mendidik anak dengan proses pendidikan melalui aktifitas jasmani dan olahraga.

Pendidikan jasmani merupakan suatu proses pendidikan yang pembelajarannya melalui aktifitas jasmani dan membiasakan hidup sehat yang mengacu pada pertumbuhan dan perkembangan jasmani secara baik. Voltmer dkk dalam Winarno (2006:03) menjelaskan bahwa tentang tujuan pendidikan jasmani mengembangkan individu baik fisik, mental, moral, sosial, estetika, emosional, intelektual, dan juga kesehatan.

Setiap sekolah melaksanakan proses pembelajaran Pendidikan Jasmani mulai dari tingkat sekolah dasar hingga sekolah menengah. Salah satu Sekolah Menengah Pertama yang turut berperan serta dalam melaksanakan proses pembelajaran pendidikan jasmani dalam usaha meningkatkan dan mengembangkan kesehatan serta kebugaran jasmani adalah Sekolah Menengah Pertama Negeri 4 Kota Pariaman. Untuk mencapai hal itu maka di Sekolah Menengah Pertama Negeri 4 Kota Pariaman melakukan kegiatan Penjasorkes rutin sekali seminggu dan juga melakukan kegiatan ekstrakulikuler dalam mengembangkan bakat dan minat siswa dalam bidang olahraga.

Tingkat kebugaran jasmani merupakan faktor yang dianggap penting agar tercapainya tujuan pendidikan jasmani olahraga pada khususnya dan tujuan pendidikan nasional pada umumnya. Salah satu jalan untuk memelihara atau meningkatkan kebugaran jasmani dengan melakukan olahraga secara teratur dan aktifitas fisik sehari-hari yang bermanfaat untuk kesehatan.

Menurut Pate dalam Agus (2012:27) mengemukakan bahwa faktor-faktor yang mempengaruhi kebugaran jasmani seseorang adalah aktivitas, keturunan, usia, jenis kelamin. Banyak faktor lain yang mempengaruhi tingkat kebugaran jasmani

4) Sepriadi. Saat ini Dosen Jurusan Pendidikan Olahraga Fakultas Ilmu Keolahragaan Universitas Negeri Padang

4) Zalfendi. Saat ini Dosen Jurusan Pendidikan Olahraga Fakultas Ilmu Keolahragaan Universitas Negeri Padang

4) Mardayanti. Saat ini Mahasiswa Jurusan Pendidikan Olahraga Fakultas Ilmu Keolahragaan Universitas Negeri Padang 
siswa diantaranya yaitu usia, jenis kelamin, kebiasaan siswa dalam aktifitas fisik seperti latihan-latihan olahraga dan aktifitas bermain, sarana dan prasarana yang baik dapat mempengaruhi siswa aktif dalam pembelajaran penjasorkes yang dalam proses pembelajarannya erat kaitannya dengan kerja fisik, lingkungan yang bersih dan nyaman, pengetahuan dan pendidikan, ekonomi orang tua, istirahat yang cukup, serta kondisi fisik, semua ini dapat mempengaruhi tingkat kebugaran jasmani siswa.

Aktifitas siswa dalam pembelajaran penjasorkes di SMP N 4 Kota Pariaman sangat mempengaruhi tingkat kebugaran jasmani siswa tersebut, dan dalam peneliti ini lebih difokuskan kepada kelas unggul dan kelas reguler. Dan di sekolah ini adanya program kelas unggul dan kelas reguler dimana pembagian kelas ini dilakukan untuk meningkatkan potensi peserta didik. Pembagian ini dilakukan pada saat siswa kelas VII naik ke kelas VIII atau disaat setelah ujian semester 2 saat kenaikan kelas. Dimana setiap kelas yang siswanya memasuki rangking 5 besar maka siswa tersebut digabungkan dalam satu kelas yaitu kelas unggul. Dan selebihnya dikategorikan sebagai kelas reguler.

Umumnya semua siswa berpotensi dan berprestasi. Kelas unggul yang dikenal dengan kelas yang rajin dan unggul dalam aktifitas akademik serta non akademik, disatukan agar dapat bersaing menjadi yang terbaik. Sedangkan kelas reguler ada sebagian siswanya yang aktif di kegiatan non akademik namun kurang aktif di aktifitas akademik bersaing menjadi lebih baik.

Dengan adanya program kelas unggul dan kelas reguler ini ternyata memberikan dampak positif dan negatif bagi siswa. Karena kelas unggul berbeda dengan kelas reguler. Siswa di kelas unggul dituntut atau dikenal dengan kelas terbaik dalam segala mata pelajaran, termasuk pembelajaran penjasorkes. Sedangkan siswa di kelas reguler dikenal dengan kelas yang kurang baik dalam mata pelajaran umum, namun cenderung suka dengan kegiatan di luar kelas termasuk pembelajaran

4) Sepriadi. Saat ini Dosen Jurusan Pendidikan Olahraga Fakultas Ilmu Keolahragaan Universitas Negeri Padang

4) Zalfendi. Saat ini Dosen Jurusan Pendidikan Olahraga Fakultas Ilmu Keolahragaan Universitas Negeri Padang

4) Mardayanti. Saat ini Mahasiswa Jurusan Pendidikan Olahraga Fakultas Ilmu Keolahragaan Universitas Negeri Padang 
penjasorkes. Maka belum diketahui secara pasti perbedaan tingkat kebugaran jasmani kelas unggul dan kelas reguler di SMPN 4 Kota Pariaman ini.

Hal ini terlihat dari sikap dan penampilan fisik, serta kemampuan mereka dalam melakukan berbagai aktifitas pembelajaran penjasorkes. Sesuai dengan observasi yang penulis lakukan dilapangan ketika mereka mengikuti pembelajaran penjasorkes, dimana siswa kelas unggul terlihat lebih lambat dalam melakukan gerakan karena siswa kelas unggul lebih banyak melakukan aktifitas belajar dan cendrung tidak berminat terhadap pelajaran penjasorkes sedangkan siswa kelas reguler lebih bersemangat dalam melakukan gerakan karena siswa kelas reguler lebih bersemangat dan umumnya siswa kelas reguler kurang suka berada dikelas. Jika ada waktu luang mereka lebih senang melakukan aktifitas olahraga dilapangan misalnya bermain basket atau sepak bola.

\section{METODE PENELITIAN}

Jenis penelitian yang digunakan dalam penelitian ini adalah jenis penelitian perbandingan (comparative research) yaitu penelitian yang membandingkan satu kelompok sampel dengan kelompok sampel lainnya berdasarkan variabel atau ukuran-ukuran tertentu (Maksum, 2009:53). Tempat pelaksanaan penelitian dan pengambilan data adalah di lapangan Sekolah Menegah Pertama Negeri 4 Kota Pariaman.

Populasi dalam penelitian ini adalah siswa di Sekolah Menegah Pertama Negeri 4 Kota Pariaman yang berjumlah 611 siswa. Teknik penarikan sampel dalam penelitian ini adalah purposive sampiling sehingga sampel penelitian ini adalah kelas Unggul yang berjumlah 29 orang dan 26 di kelas reguler. Instrumen yang digunakan dalam penelitian ini yaitu hasil Tes Kesegaran Jasmani Indonesia (TKJI) untuk anak usia 13-15 tahun.

4) Sepriadi. Saat ini Dosen Jurusan Pendidikan Olahraga Fakultas Ilmu Keolahragaan Universitas Negeri Padang

4) Zalfendi. Saat ini Dosen Jurusan Pendidikan Olahraga Fakultas Ilmu Keolahragaan Universitas Negeri Padang

4) Mardayanti. Saat ini Mahasiswa Jurusan Pendidikan Olahraga Fakultas Ilmu Keolahragaan Universitas Negeri Padang 
Teknik analisis data yang digunakan dalam penelitian ini adalah menggunakan Uji normalitas dan uji homogenitas yang tujuannya untuk mengetahui apakah data yang digunakan dari populasi yang berdistribusi normal dan homogen. Uji normalitas dilakukan dengan uji liliefors dan uji homogenitas varians dan dilanjutkan dengan uji beda mean (uji t) Independen sampel yang jumlah sampel masing - masing kelompok berbeda.

\section{HASIL PENELITIAN DAN PEMBAHASAN}

\section{A. Deskripsi Data}

Deskripsi data hasil penelitian dapat diketahui seperti tabel 1 di bawah ini:

Tabel 1. Deskripsi Data

\begin{tabular}{|l|l|l|}
\hline & Kelas Unggul & Kelas Reguler \\
\hline $\begin{array}{l}\text { Mean (Rata- } \\
\text { rata) }\end{array}$ & 14,13 & 13,23 \\
\hline SD & 2,23 & 1,98 \\
\hline Kategori & Sedang & Kurang \\
\hline
\end{tabular}

Berdasarkan hasil penelitian yang terdapat pada tabel 1 di atas dapat diketahui bahwa tingkat kebugaran jasmani siswa kelas unggul lebih baik daripada siswa kelas reguler dimana kebugaran jasmani siswa kelas unggul berada pada kategori sedang sedangkan kebugaran jasmani siswa kelas reguler berada pada kategori kurang.

\section{B. Uji Persyaratan Analisis}

\section{1) Uji Normalitas}

Tabel 2. Pengujian Normalitas dengan Uji Lilliefors

\begin{tabular}{|l|l|l|l|}
\hline Kelompok & $\mathbf{L}_{\text {observasi }}$ & $\mathbf{L}_{\text {tabel }}$ & Keterangan \\
\hline Kelas unggul & 0,1088 & 0,167 & Normal \\
\hline Kelas reguler & 0,1632 & 0,167 & Normal \\
\hline
\end{tabular}

4) Sepriadi. Saat ini Dosen Jurusan Pendidikan Olahraga Fakultas Ilmu Keolahragaan Universitas Negeri Padang

4) Zalfendi. Saat ini Dosen Jurusan Pendidikan Olahraga Fakultas Ilmu Keolahragaan Universitas Negeri Padang

4) Mardayanti. Saat ini Mahasiswa Jurusan Pendidikan Olahraga Fakultas Ilmu Keolahragaan Universitas Negeri Padang 
Berdasarkan pada tabel 2 di atas yang dengan menggnakan taraf signifikansi $\alpha=0,05$ didapatkan $\mathrm{L}_{\text {tabel }} 0,167$. Jadi $\mathrm{L}_{0}(0,1088)<\mathrm{L}_{\text {tabel }}(0,167)$ pada kelas unggul dan $\mathrm{L}_{0}(0,1632)<\mathrm{L}_{\text {tabel }}(0,167)$ pada kelas reguler, dengan demikian dapat disimpulkan bahwa data dari kedua kelompok data berasal dari populasi yang berdistribusi normal.

\section{2) Uji Homogenitas}

Tabel 3. Pengujian Homogenitas varians

\begin{tabular}{|l|l|l|l|}
\hline Kelompok & $\mathbf{F}_{\text {hitung }}$ & $\mathbf{F}_{\text {tabel }}$ & Keterangan \\
\hline $\begin{array}{l}\text { Kelas unggul } \\
\text { dan kelas }\end{array}$ & 1,26 & 1,91 & Homogen \\
reguler & & & \\
\hline
\end{tabular}

Berdasarkan pada tabel 3 di atas dengan menggunakan derajat kebebasan (n1- 1 ), (n2- 1) dan taraf signifikansi $\alpha=0,05$ didapatkan nilai $F_{\text {tabel }}=1,91$. Karena $F_{\text {hitung }}(1,26)$ $<F_{\text {tabel }}(1,91)$, maka dapat disimpulkan bahwa kedua varians tersebut homogen.

\section{3) Uji Hipotesis}

Tabel 4. Pengujian Hipotesis

\begin{tabular}{|l|l|l|ll|}
\hline Kelompok & $\mathrm{t}_{\text {hitung }}$ & $\mathrm{t}_{\text {tabel }}$ & Keterangan & \\
\hline $\begin{array}{l}\text { Kelas unggul } \\
\text { dan kelas }\end{array}$ & 1,625 & 1,676 & $\mathrm{H}_{0}$ diterima $\mathrm{H}_{\mathrm{a}}$ \\
reguler & & & ditolak & \\
\hline
\end{tabular}

Berdasarkan pada tabel 4 di atas dapat disimpulkan bahwa tidak terdapat perbedaan yang signifikan antara tingkat kebugaran jasmani kelas unggul dan tingkat kebugaran jasmani kelas reguler. Hal ini karena $t_{\text {hitung }}(1,625)<t_{\text {tabel }}(1,675)$, maka $\mathrm{H}_{0}$ diterima dan $\mathrm{H}_{\mathrm{a}}$ ditolak.

\section{Pembahasan}

Berdasarkan hasil penelitian dapat diketahui bahwa rata-rata tingkat kebugaran jasmani siswa kelas unggul adalah 14,23 dan berada pada kategori sedang,

4) Sepriadi. Saat ini Dosen Jurusan Pendidikan Olahraga Fakultas Ilmu Keolahragaan Universitas Negeri Padang

4) Zalfendi. Saat ini Dosen Jurusan Pendidikan Olahraga Fakultas Ilmu Keolahragaan Universitas Negeri Padang

4) Mardayanti. Saat ini Mahasiswa Jurusan Pendidikan Olahraga Fakultas Ilmu Keolahragaan Universitas Negeri Padang 
sedangkan rata-rata tingkat kebugaran jasmani siswa kelas reguler adalah 13,23 dan berada pada kategori kurang. Hal ini dapat diketahui bahwa tingkat kebugaran jasmani siswa kelas unggul lebih baik daripada siswa kelas reguler.

Akan tetapi, berdasarkan hasil penghitungan statistik didapat nilai $t_{\text {hitung }}$ $(1,625)<t_{\text {tabel }}(1,675)$. Hal ini dapat disimpulkan bahwa tidak terdapat perbedaan yang signifikan antara tingkat kebugaran jasmani kelas unggul dan tingkat kebugaran jasmani kelas reguler di Sekolah Menengah Pertama Negeri 4 Kota Pariaman. Hal ini karena dari hasil penelitian diperoleh data bahwa perbedaan tingkat kebugaran jasmani siswa kelas unggul tidak berbeda secara signifikan dibandingkan dengan kelas reguler.

Kebugaran jasmani adalah salah satu faktor yang menentukan dalam kehidupan sehari-hari. Begitu juga bagi siswa yang belajar pendidikan jasmani olahraga kesehatan sangat memerlukan sekali ketekunan serta daya tahan tubuh yang lebih tinggi dalam mengikuti materi-materi pelajaran pendidikan jasmani dan olahraga.

Kebugaran jasmani merupakan kemampuan tubuh seseorang untuk melakukan pekerjaan sehari-hari tanpa menimbulkan kelelahan yang berarti. Kebugaran jasmani merupakan salah satu hal yang penting bagi tercapainya tujuan proses belajar mengajar di sekolah. Seseorang tidak akan mendapatkan hasil belajar yang baik (optimal) tanpa disertai dengan kesegaran jasmani yang baik. Dengan demikian kebugaran jasmani merupakan faktor yang sangat penting dalam kaitannya dengan kemampuan dan keberhasilan belajar seseorang.

Masih kurangnya tingkat kebugaran jasmani pada siswa Sekolah Menengah Pertama Negeri 4 Kota Pariaman ini juga dipengaruhi oleh faktor kurangnya aktivitas fisik yang teratur dilakukan oleh siswa Sekolah Menengah Pertama Negeri 4 Kota Pariaman. Salah satu faktornya adalah kegiatan ekstrakurikuler di luar jam sekolah kurang diminati oleh siswa. Selain itu juga dipengaruhi oleh perkembangan teknologi

4) Sepriadi. Saat ini Dosen Jurusan Pendidikan Olahraga Fakultas Ilmu Keolahragaan Universitas Negeri Padang

4) Zalfendi. Saat ini Dosen Jurusan Pendidikan Olahraga Fakultas Ilmu Keolahragaan Universitas Negeri Padang

4) Mardayanti. Saat ini Mahasiswa Jurusan Pendidikan Olahraga Fakultas Ilmu Keolahragaan Universitas Negeri Padang 
yang meningkat pesat seperti kendaraan. Akibatnya orang-orang akan lebih suka naik kendaraan dibandingkan dengan berjalan kaki.

Ada banyak faktor yang mempengaruhi kebugaran jasmani siswa, diantaraya menurut Sharkey dalam Fadila (2015: 9), “faktor-faktor yang mempengaruhi kebugaran meliputi: hederitas, latihan, jenis kelamin, usia, lemak tubuh, dan aktivitas". Lebih lanjut dijelaskan bahwa faktor umur akan sangat mempengaruhi kebugaran jasmani seseorang karena semakin usia bertambah maka kebugaran jasmai akan semakin menurun, oleh sebab itu jika kita melaksanakan olaraga dengan teratur maka penurunan ini dapat dikurangi sampai 50\% atau separuhnya. Begitu juga dengan faktor jenis kelamin juga mempengaruhi kebugaran jasmani. Anak laki - laki mempunyai kebugaran jasmani yang lebih baik dari anak perempuan.

Selain itu untuk meningkatkan kebugaran jasmani anak, tentu orang tua harus menyeleksi bentuk-bentuk permainan yang dilakukan dan dapat merangsang komponen-komponen kebugaran jasmani seperti: ketahanan jantung paru, kekuatan otot, ketahanan otot, komposisi tubuh dan fleksibilitas. Dapat dicontohkan bila anakanak lebih banyak melakukan kegiatan permainan pasif, maka orang tua berusaha mendorong untuk melakukan bentuk permainan aktif.

Perbedaan tingkat kebugaran jasmani siswa kelas unggul dengan kelas reguler di Sekolah Menengah Pertama Negeri 4 Kota Pariaman tersebut sesuai dengan teori yang menyatakan bahwa kepadatan aktivitas belajar di lingkungan sekolah akan menekan kebebasan anak untuk bergerak. Kebutuhan mereka akan gerak tidak bisa terpenuhi karena keterbatasan waktu dan kesempatan, padahal aktivitas gerak sangat penting untuk menunjang kebugaran jasmani anak. "Seorang yang hidup sehari-hari lebih aktif akan memiliki tingkat kebugaran jasmani yang lebih baik bila dibandingkan dengan mereka yang hidup sehari-hari kurang aktif" (Sastropanoelar dalam Yohandika 2013:9). Dari teori itu dapat disimpulkan bahwa tingkat kebugaran

4) Sepriadi. Saat ini Dosen Jurusan Pendidikan Olahraga Fakultas Ilmu Keolahragaan Universitas Negeri Padang

4) Zalfendi. Saat ini Dosen Jurusan Pendidikan Olahraga Fakultas Ilmu Keolahragaan Universitas Negeri Padang

4) Mardayanti. Saat ini Mahasiswa Jurusan Pendidikan Olahraga Fakultas Ilmu Keolahragaan Universitas Negeri Padang 
jasmani siswa kelas unggul secara teori lebih rendah daripada siswa kelas reguler karena siswa kelas unggul memiliki keterbatasan aktivitas gerak karena jadwal belajar yang padat. Dari hal tersebut dapat diambil asumsi bahwa perbedaan tingkat kebugaran tersebut dipengaruhi karena aktivitas gerak dan faktor-faktor lain yang tidak bisa dikendalikan seperti kegiatan sehari-hari siswa.

Lebih lanjut Sepriadi (2017:196) menjelaskan bahwa kebugaran jasmani juga dipengaruhi oleh aktifitas fisik dan latihan olahraga. Hal ini berarti bahwa tidak terdapatnya perbedaan yang berarti antara kebugaran jasmani siswa kelas unggul dan reguler karena tidak terdapatnya perbedaan antara aktivitas fisik dan latihan yang dilakukan oleh siswa. Hal ini didasarkan karena antara siswa kelas unggul dan kelas reguler memiliki beban yang sama sebagai seorang pelajar hanya saja dibedakan oleh persaingan di dalam kelas. Dimana pada kelas unggul persaingan dalam bidang akademik lebih berat dibanding kelas reguler karena dikelas unggul semua siswa yang unggul dibidang akademik jika dibandingkan kelas reguler.

\section{KESIMPULAN}

Berdasarkan hasil penelitian yang telah diuraikan mengenai tingkat kebugaran jasmani pada siswa kelas unggul dan kelas reguler di Sekolah Menengah Pertama Negeri 4 Kota Pariaman, maka dapat diambil kesimpulan bahwa: Tidak terdapat perbedaan yang signifikan antara tingkat kebugaran jasmani kelas unggul dan tingkat kebugaran jasmani kelas reguler.

\section{DAFTAR RUJUKAN}

Agus, Apri. 2012. Olahraga Kebugaran Jasmani Sebagai Suatu Pengantar. Padang : Sukabina Press

Fadila. 2015. Tinjauan Kebugaran Jasmani dan Status Gizi siswa Tunagrahita ringan

\section{Sekolah Luar Biasa Negeri 2 Padang. Jurnal FIK UNP}

4) Sepriadi. Saat ini Dosen Jurusan Pendidikan Olahraga Fakultas Ilmu Keolahragaan Universitas Negeri Padang

4) Zalfendi. Saat ini Dosen Jurusan Pendidikan Olahraga Fakultas Ilmu Keolahragaan Universitas Negeri Padang

4) Mardayanti. Saat ini Mahasiswa Jurusan Pendidikan Olahraga Fakultas Ilmu Keolahragaan Universitas Negeri Padang 
Maksum, Ali. 2009. Statistik dalam Olahraga. Surabaya: Fakultas Ilmu Keolahragaan

Paturisi. 2012. Managemen Pendidikan Jasmani dan Olahraga. Jakarta: Rineka Cipta.

Sepriadi. 2017. Kontribusi Status Gizi dan Kemampuan Motorik terhadap Kesegaran Jasmani Siswa Sekolah Dasar. Jurnal Keolahragaan Volume 5 Nomor 2 September 2017.

Winarno. 2006. Perspektif Pendidikan Jasmani dan Olahraga. Jurnal. Malang: FIP UNM

4) Sepriadi. Saat ini Dosen Jurusan Pendidikan Olahraga Fakultas Ilmu Keolahragaan Universitas Negeri Padang

4) Zalfendi. Saat ini Dosen Jurusan Pendidikan Olahraga Fakultas Ilmu Keolahragaan Universitas Negeri Padang

4) Mardayanti. Saat ini Mahasiswa Jurusan Pendidikan Olahraga Fakultas Ilmu Keolahragaan Universitas Negeri Padang 